\title{
THE EFFECT OF INQUIRY-BASED LEARNING ON STUDENTS' CRITICAL THINKING IN READING
}

\author{
${ }^{\# 1}$ Abdul Wahab, ${ }^{* 2}$ Terasne \\ ${ }^{\# 1}$ Faculty of Education and Education of Science, Qamarul Huda University, Indonesia \\ ${ }^{* 2}$ Faculty of Culture, Management, and Business, UNDIKMA, Indonesia \\ Corresponding Author Email: terasne@ikipmataram.ac.id
}

\begin{abstract}
A B S T R A C T S
This research was aimed to find out the significant effect of InquiryBased Learning on students' critical thinking in reading at third-semester students of Faculty of Education, and Education of Science Qamarul Huda University, Bagu, Central Lombok in academic year 2019/2020. This research was experimental research that categorized by preexperimental One Group Pretest-Posttest design. The population of this research was at third-semester students of Faculty of Education, and Education of Science Qamarul Huda University, Bagu, Central Lombok which consisted of 18 students and using surfeited sampling. The instrument of collecting the data was used multiple-choices and questionnaires. In this research, the writer rendered treatment and prepared a test in the form of multiple-choices to look the effect of Inquiry-Based Learning and questionnaires for look the critical thinking. The result of data analysis indicated at third-semester students of Faculty of Education, and Education of Science Qamarul Huda University, Bagu, Central Lombok attained high score on post-test whom were treated by Inquiry-Based Learning. It means that Inquiry-Based Learning gave a significant effect on critical thinking of students in reading. It was proven by the lowest and highest in pre-test score was 30 and 50 and post-test was 35 and 65 . Then, the result of hypothesis testing was the alternative hypothesis accepted. It was provable that t-test was higher than $\mathrm{t}$-table, which was the score of t-test was 3.81 and t-table in df 17 with significant 0.05 was 1.753 .
\end{abstract}

\begin{tabular}{l}
\hline A R T I C L E I N F O \\
\hline Article History: \\
Received: May, 2020
\end{tabular}

Revised: June, 2020

Published: June, 2020

\author{
Keywords: \\ Inquiry-Based Learning, \\ Critical thinking, \\ Reading,
}

How to cite: Wahab, A., \& Terasne, T. (2020). The Effect of Inquiry-Based Learning on Students' Critical Thinking in Reading. Jo-ELT (Journal of English Language Teaching) Fakultas Pendidikan Bahasa \& Seni Prodi Pendidikan Bahasa Inggris IKIP, 7(1), 26-30. doi:https://doi.org/10.33394/jo-elt.v7i1.2690

\section{INTRODUCTION}

There are four academic skills in English language that should be mastered by the students such as listening, reading, writing, and speaking. In mastering English well. Especially reading is one of the important skills in teaching English. where reading is a process that is applied and conducted by a reader to acquire a message that has been told by a writer in writing script. Reading enable people to find out information from a variety of text, newspapers, magazine, advertisement, brochures, etc. As part of language skill, reading plays an important role in the success of language learning. In the reading activity, we are not only reading the text but also trying to understand what we are reading. 
The general objective of reading is that the students can understand and interpret the content of reading texts through observation and interpretation. Related to English reading in general, there are some advantages students may obtain. Students may be able to find a lot of new information to expand their knowledge and to enrich their vocabulary. The students are good in reading, they can rapidly get the main idea of the text, know the explicit and implicit information about the text, finding detailed information, finding the word references, making an inference, etc.

In the educational field, in doing the observation at third-semester students of Faculty of Education, and Education of Science Qamarul Huda University, Bagu, Central Lombok the researcher found that the students are lack of constructing the meaning in reading, especially to finding main ideas, specific, and implicit information from the text. it because the students are lack of thinking critically. Where having the ability to think critically is an important skill that should have by students because critical thinking plays an important role for the students. Critical thinking is the best ability to understand a concept fully, and the best way to solve the problem since it requires looking at the issue from several standpoints before reaching a final decision. Critical thinking is very important in reading.

Based on the problem that the researcher found at third-semester students of Faculty of Education, and Education of Science Qamarul Huda University, Bagu, Central Lombok the researcher wants to give the appropriate strategy in teaching reading to solve the problem and the strategy that the researcher wants to give is Inquiry-Based Learning.

Inquiry-Based learning is one kind of strategy that demanded students to think where the students were involved to formulate questions, observation, and also finding the information. According to Paula (2006: 20) inquiry-based learning is a strategy to learning that involves a process of exploring the natural or material world, and that leads to asking questions, doing observation, and discussing the result of the observation to get the conclusion. It provides students the opportunity to construct the understanding necessary to produce deeper learning. Inquiry-Based Learning strategy also serves as a stimulus for learning, thinking, and questioning. From those explanations, the researcher decides to investigate the effect of Inquiry-Based Learning strategy in teaching reading at third-semester students of Faculty of Education, and Education of Science Qamarul Huda University, Bagu, Central Lombok in academic year 2019/2020.

Reading is the understanding of the written word, the understanding of the content that is being read, and the construction of meanings of the text. Reading is a purposeful and active process. A reader reads to understand, to remember what is understood and put the understanding to use. A reader can read a text to learn, to find out information, or to be entertained (Healy, 2002:3).

According to Leung (1998: 12) inquiry can be viewed as a process for answering questions and solving problems based on facts and observations. At the classroom level, inquiry is a teaching strategy. The definition states that Inquiry-Based Learning gives the teacher the opportunity to help students learn the content and course concept by having them chance to explore a question, develop the information, and research a hypothesis. Thus, giving students more opportunity to inflict on their own learning, gain a deeper understanding of the course concepts in an integrated fashion, and become better critical thinkers. In addition, the inquiry approach is more focused on using and learning as a means to develop information-processing and problem-solving skills. The system is more students centered, with the teacher as a facilitator of learning. 
Critical thinking is the correct assessing of statements (Ennis, 1962: 179). Critical thinking includes the ability to respond to material by distinguishing between facts and opinions or personal feelings, judgments and inferences, inductive and deductive arguments, and the objective and subjective. In addition Ennis (1992) in Mark Mison (2008: 3), maintained that the skills associated with critical thinking can be learned independently of specific disciplines, and can be transferred from one domain to another. For him, the process of critical thinking is deductive: it involves applying the principles and skills of critical thought to a particular discipline.

\section{RESEARCH METHOD}

The experimental method was used in this research. Thus, experimental research is the proof of a hypothesis which seeks to make up two factors into a casual relationship through the study of contrasting situations which have been controlled on all factors the one of interest, the latter being either the hypothetical cause or the hypothetical effect (Singh, 2006:135). The research was a categorized pre-experimental design because in this study the researcher only used an experimental class without control class. In this case, the researcher was used One Group Pretest-Posttest.

\section{Population and Sample}

The population in this study was at third-semester students of Faculty of Education, and Education of Science Qamarul Huda University, Bagu, Central Lombok in academic year 2019/2020.There was only one class of the third-semester students consisted of 18 students. The researcher used a surfeited sampling method for choosing the sample. So, the researcher had determined the sample using surfeited sampling. Surfeited Sampling is the technique to determine sample if the whole population use as sample and the population is less than 30 students (Sugiyono 2014: 85). Based on the construct above, the researcher has used the whole of the population as sample; the populations are 18 students and it also for sample.

\section{Instruments}

The instrument was used in this research was multiple choice that consist 50 items to measure the students' reading along with critical thinking and questionnaires to know their students' respons on Inquiry technique based-learning by choosing the option on questionnaires which was Likert scale which consisted of 7 items. Each item has 4 options with the first option scores 4 (Very Agree), the second option scores 3 (Agree), the third option scores 2 (Disagree), and the last option scores 1 (Very not agree). And for multiple choice that consist 50 items. Each correct answer was scored 5 and if incorrect was 0 . So, the highest possible score for students was 20. The technique data analysis employed a descriptive analysis to know the score of the mean, median, and mode. The inferential statistic was to measure the data significant or not. Then, the result of the t-test will compare to t-table to know significant or not.

\section{Data Analysis}

In this study, the researcher wants to show the statistical analysis of the data obtained, this analysis leads the discussion toward the finding at the investigation. There are several steps to measuring whether between them are having significance effect such as descriptive statistic and T-test for reading test and questionnaire for measure students' critical thinking. 


\section{RESEARCH FINDINGS AND DISCUSSION Research Findings}

a. Data description of Post-Test

The result of data analysis designates that the highest score was 65 and the lowest score was 35. The mean score was 49.1 , the median score was 49.8 , the mode score was 50.25 , the range was 30, the standard deviation was 4.26 and the frequency distribution as follows:

b. Data Descriptions of Questionnaires Computation Pre-test

$(\mathrm{RxV})(\mathrm{RxV})+(\mathrm{RxV})+(\mathrm{RxV})=(\mathrm{AV}: \mathrm{AR})=\mathrm{FV}$

1. $(1 \times 4)+(4 \times 3)+(7 \times 2)+(8 \times 1)=38: 18=2.11$

2. $(2 \times 4)+(3 \times 3)+(6 \times 2)+(7 \times 1)=34: 18=1.88$

3. $(1 \times 4)+(1 \times 3)+(10 \times 2)+(6 \times 1)=33: 18=1.83$

4. $(2 \times 4)+(2 \times 3)+(8 \times 2)+(6 \times 1)=38: 18=2.00$

5. $(1 \times 4)+(1 \times 3)+(4 \times 2)+(12 \times 1)=27: 18=1.5$

(L)

6. $(1 \times 4)+(2 \times 3)+(1 \times 2)+(14 \times 1)=29: 18=1.61$

7. $(1 \times 4)+(3 \times 3)+(2 \times 2)+(12 \times 1)=29: 18=1.61$

The data computation above shows the amount of respondent who chooses the option of questionnaires which was consist of 7 items Each items has 4 options with the first option scores 4, the second option scores 3, the third option scores 2 , and the last option scores 1.

The amount of respondents was 18 students at third-semester students of Faculty of Education, and Education of Science Qamarul Huda University, Bagu, Central Lombok in academic year 2020/2021.

c. Data Description of Questionnaires Computation Post-test

$(\mathrm{RxV})+(\mathrm{RxV})+(\mathrm{RxV})+(\mathrm{RxV}=(\mathrm{AV}: \mathrm{AR})=\mathrm{FV}$

1. $(8 \times 4)+(6 \times 3)+(2 \times 2)+(2 \times 1)=56: 18=3.11$

2. $\quad(10 \times 4)+(5 \times 3)+(1 \times 2)+(2 \times 1)=59: 18=3.27$

3. $(5 \times 4)+(4 \times 3)+(4 \times 2)+(5 \times 1)=45: 18=2.5$

4. $(13 \times 4)+(3 \times 3)(2 \times 2)+(1 \times 1)=70: 18=3.8(\mathrm{H})$

5. $(10 \times 4)+(5 \times 3)+(1 \times 2)+(2 \times 1)=59: 18=3.27$

6. $(6 \times 4)+(2 \times 3)+(4 \times 2)+(6 \times 1)=44: 18=2.44$

7. $(17 \times 4)+(6 \times 3)+(4 \times 2)+(1 \times 1)=55: 18=3.05$

The result of data computation above shows clearly that strategy of Inquiry-Based Learning has effect toward students' critical thinking in reading at third-semester students of Faculty of Education, and Education of Science Qamarul Huda University, Bagu, Central Lombok in academic year 2019/2020. There were a lot of students classified as high critical thinking $(\mathrm{H})$ after treated by Inquiry-Based Learning then before using this strategy all the students was classified as low (L) critical thinking.

\section{Discussion}

Based on the computation of the data the researcher found the effect of Inquiry-Based Learning toward students' critical thinking in reading. Where the most of students were classified as high $(\mathrm{H})$ critical thinking. So, the theory of Leung (1998: 12), that said that inquiry is a teaching strategy designed to teach students how to deal with questions and problems encountered in various important generic skill through a variety of learning experiences that help students to be critical thinker was proven after the procedure of Inquiry apply in the learning process. After students had critical thinking the extent of their ability in reading also have developed because having critical thinking is an important skill for them where critical thinking is the ability to understand a concept fully (Selleck, 1993) that helped them to comprehended the content in reading. It can be seen from the result of the students' score had been analyzed by using statistical computation and the result as follows: 
The mean score of post-test 1 was $49.1>41.66$ the mean score pre-test. The median score of post-test 49.8 , the median score of pre-test was 40.14 , the mode score of post 50.25 the mode score of pre-test was 39.5. It means that the procedure of inquiry which system was centered in the students make students were more active than teacher and could give positive effect toward students critical thinking where critical thinking also could help students in comprehending the content of reading because students were able to use their thinking skill in analysis and evaluate the information so they can classify every information in reading text. And the result computation was indicated that the students could increase their reading comprehension with their critical thinking ability through the strategy of Inquiry-Based Learning. It can be seen in the last result of the last process of statistical data computation where the t-test was $3.81>$ t-tabel 1.753 in degree of freedom $(\mathrm{df}=\mathrm{N}-1=17)$ with a significant test $5 \%$. So, Inquiry-Based Learning is effective to develop students critical thinking in teaching reading.

\section{CONCLUSION}

From the data analysis, the researcher found that the score of the t-test was 3.81 and the score of t-table 2.101. The score showed that the score of the t-test was higher than the $\mathrm{t}$ table. This indicated that the effect of the treatment was effective and gave an interpretation that the strategy of Inquiry-Based Learning gave a positive effect toward students' critical thinking also in reading at third-semester students of Faculty of Education, and Education of Science Qamarul Huda University, Bagu, Central Lombok. Moreover, it meant that the alternative hypothesis $(\mathrm{Ha})$ was accepted and the null hypothesis $(\mathrm{Ho})$ was rejected.

\section{REFERENCES}

Chaty, H. (2002). The Law Down on the National Reading Panel. Parent Educational Advocacy Training Center: Peatc.

Ennis, R. H. (1993). Critical Thinking Assessment. Ohio State University.

Erni, J. (2015). The effect of STAD (students team achievment division) toward students' critical thinking in speaking, Thesis. Unpublish. IKIP Mataram.

Leung, W.L. (2004). Inquiry Learning in Primary Classroom: The Project Approach. Retrieved March 9, 2012, from http://ijl.cgpublisher.com/product/pubb.30/prpd.824.

Nurtaliana. (2013). The effect of inquiry-based learning strategy in the writing ability. Unpublished Thesis. Yogyakarta.

Selleck, D. (1993.) Definition and purpose for critical thinking (haper). Colorando State University.

Sing, Y. K. (2006). Fundamental of Research Methodology and Statistics. New Delhi: Age International.

Subana., Rahadi, M., \& Sudrajat. (2000). Statistik Pendidikan. Bandung: Pustaka Setia. Sudijono, A. (2006). Pengantar Statistik Pendidikan. Jakarta: Raja Grapfindo Persada. Sugiyono. (2013). Metode Penelitian Kombinasi (Mixed Methods). Bandung: Alfabeta. 